\title{
UJI DEGRADASI IN VITRO ADF DAN NDF RUMPUT RAJA (Pennisetum purpuroides) MENGGUNAKAN INOKULUM CAIRAN FESES
}

\author{
M. Afdal dan Yun Alwi \\ Fakultas Peternakan Universitas Jambi, Kampus Pinang Masak \\ Jalan Jambi KM 15 Mandalo Darat Muara Bulian 36361
}

\begin{abstract}
ABSTRAK
Tujuan penelitian ini adalah untuk mengetahui degradasi neutral detergent fiber (NDF) dan acid detergent fiber (ADF) dan protein kasar (PK) dari rumput raja (RR) secara in vitro menggunakan cairan feses sebagai inokulum. Sampel RR diambil dari Fapet Farm Fakultas Peternakan Universitas Jambi, kemudian dipotongpotong dengan ukuran panjang $5 \mathrm{~cm}$ kemudian dikering dan digiling dengan ukuran $1 \mathrm{~mm}$ mash. Feses dan cairan rumen diambil dari satu ekor sapi berfistula rumen. Sampel kemudian diinkubasi untuk mengetahui degradasi NDF, ADF dan PK. Penelitian ini menggunakan Rancangan Acak Lengkap (5x4) dengan lima perlakuan sebagai berikut A (Cairan rumen (kontrol)), B (Cairan feses), C (Cairan feses dan 2,5\% gula), D (Cairan feses, 2,5\% gula dan 2,5\% urea) dan E (Cairan feses dan 2,5\% urea). Hasil percobaan menunjukkan bahwa degradasi in vitro NDF dan ADF dari RR menunjukkan perbedaan nyata $(\mathrm{P}<0,05)$. Dapat disimpulkan bahwa penggunaan cairan feses dan penambahan gula sebagai sumber energi dan urea sebagai sumber nitrogen belum optimal yang terlihat dari masih rendahnya degradasi ADF dan PK kecuali NDF jika dibandingkan dengan penggunaan cairan rumen.
\end{abstract}

Kata kunci: degradasi, inokulum, in vitro, feses, $N D F, A D F$

\section{PENDAHULUAN}

Pemanfaatan cairan feses untuk inokulum merupakan sebuah alternatif pengganti dari cairan rumen dalam percobaan in vitro. Berbagai penelitian dengan menggunakan cairan feses sebagai inokulum telah digunakan dalam percobaan in vitro (Balfe 1985; Sudirman et al, 2006; Afdal dan Toha, 2007). Hasil penelitian menunjukkan hasil yang masih bervariasi. Terakhir Zicarelli et al (2011) membandingkan inokulum feses dan cairan rumen dalam menentukan karakteristik fermentasi dari hijauan dan konsentrat dengan berbagai perbandingan.

Pada umumnya permasalahan dalam penggunaan cairan feses adalah relatif lebih sedikitnya jumlah populasi mikroba dibandingkan dengan jumlah populasi mikroba pada cairan rumen (Afdal 2003). Sehingga perlu penambahan nutrien sumber energi ataupun nitrogen yang dapat meransang peningkatan jumlah populasi mikroba dalam inokulum feses. Afdal dan Toha (2007) mencoba menambahkan urea dan ataupun gula dalam inokulum cairan feses dalam menguji kecernaan in vitro dari rumput kumpeh (Hymenachne amplexicaulis).

Rumput Raja (Pennisetum purpuroides) (RR) adalah merupakan jenis rumput unggul yang banyak digunakan sebagai sumber hijauan pakan ternak. Rumput ini telah terkenal sebagai hijauan unggul dan telah banyak dipergunakan dan dibudidayakan oleh peternak. Sehingga telah banyak informasi mengenai degradasi ataupun kecernaan serat seperti NDF dan ADF. Dalam hal ini RR sebagai hijauan unggul dapat dipergunakan sebagai referensi pembanding dalam menguji degradasi NDF dan ADF antara penggunaan cairan rumen dan ataupun cairan feses dalam percobaan in vitro. Berdasarkan informasi tersebut maka dilakukan penelitian untuk mengevaluasi degradasi NDF, ADF dan PK dari RR secara in vitro dengan menggunakan cairan feses sebagai sumber inokulum.

\section{MATERI DAN METODE}

Sampel RR diambil dari kebun Fapet Farm Fakultas Peternakan Universitas Jambi. Sampel kemudian dipotong-potong kira-kira sepanjang 5 $\mathrm{cm}$ dan dikeringudarakan dan dilanjutkan dengan pengeringan oven pada suhu $60{ }^{\circ} \mathrm{C}$. Setelah kering dihaluskan dengan penggiling dengan ukuran kirakira $2 \mathrm{~mm}$. Sampel kering ini siap untuk dipergunakan dalam uji degradasi in vitro.

Dalam penelitian ini dipergunakan seekor sapi Bali jantan berfistula rumen berumur lebih kurang tiga tahun untuk pengambilan sampel cairan ruman dan feses. Sampel cairan rumen diambil sekitar jam 07.0o pagi sebelum sapi diberi makan agar diperoleh $\mathrm{pH}$ yang relatif netral sesuai dengan prosedur standar pengambilan cairan rumen. Sedangkan feses diambil dari sapi yang sama pada saat pengeluaran feses ataupun langsung diambil dari rektum. Sapi fistula 
diberikan 100\% rumput lapangan secara ad libitum.

Cairan rumen diperoleh dengan cara memeras isi rumen dan cairan selanjutnya ditempatkan ke dalam termos pada suhu $39{ }^{\circ} \mathrm{C}$. Kemudian cairan rumen disaring dengan kain kasa empat lapis dan ditampung di dalam water bath dan dialiri dengan gas $\mathrm{CO}_{2}$ sampai dilakukan inokulasi. Pada suhu tersebut cairannya dicampurkan dengan urea dan ataupun gula sesuai dengan perlakuan.

Cairan feses juga diambil dari sapi yang sama setelah pengambilan cairan rumen sesuai dengan petunjuk Afdal (2003). Feses diambil dari rektum dengan tangan dan dimasukkan ke dalam termos pada suhu $39{ }^{\circ} \mathrm{C}$. Inokulum dipersiapkan dengan mencampur feses dan larutan saliva buatan dengan perbandingan 500:500 ml. Campuran kemudian diblender selama 20 detik. Hasil campuran ini disaring dengan kain kasa dan disimpan ke dalam water bath sebagaimana cairan rumen.

\section{Rancangan Percobaan}

Penelitian ini menggunakan Rancangan Acak Lengkap dimana untuk setiap perlakuan terdapat empat kali ulangan dengan perlakuan sebagai berikut:
A. Cairan rumen (kontrol
B. Cairan feses
C. Cairan feses dan $2,5 \%(\mathrm{~b} / \mathrm{v})$ gula
D. Cairan feses, $2,5 \%(\mathrm{~b} / \mathrm{v})$ gula dan $2,5 \%(\mathrm{~b} / \mathrm{v})$ urea
E. Cairan feses dan $2,5 \%(b / v)$ urea

\section{Parameter yang diamati}

Parameter yang diamati meliputi degradasi ADF, NDF dan protein kasar (PK) dari masing-masing perlakuan.

\section{Analisis Kimia}

Seperangkat alat in vitro sesuai dengan petunjuk Tilley dan Terry (1963) dengan beberapa modifikasi untuk mendapatkan cairan rumen ataupun feses sesuai dengan ketersediaan peralatan yang ada pada Fakultas Peternakan Universitas Jambi. Bahan kimia untuk keperluan pembuatan larutan media percobaan

Analisis kimia menggunakan seperangkat peralatan untuk analisis serat (Van Soest, 1963 untuk analisis kandungan ADF dan NDF. Untuk analisis kandungan protein kasar menggunakan analisis proksimat.

\section{Analisis statistik}

Data yang diamati diolah dengan analisis keragaman dan jika terdapat perbedaan yang nyata maka dilanjutkan dengan uji lanjut Berganda Duncan

\section{HASIL DAN PEMBAHASAN}

Degradasi NDF dari RR menunjukkan perbedaan nyata $(\mathrm{P}<0,05)$ dari masing-masing perlakuan (Tabel 1). Dibandingkan dengan kontrol terlihat bahwa penggunaan inokulum yang berasal dari cairan feses memberikan pengaruh nyata $(\mathrm{P}<0,05)$ lebih rendah terhadap degradasi NDF. Namun demikian cairan feses setelah penambahan $2,5 \%(\mathrm{~b} / \mathrm{v})$ gula dan $2,5 \%(\mathrm{~b} / \mathrm{v})$ urea menunjukkan degradasi yang nyata $(\mathrm{P}<0,05)$ lebih tinggi dari perlakuan kontrol. Dilihat dari persentasenya, hanya sedikit peningkatan degradasi NDF yaitu sekitar $0,87 \%$. Penambahan 2,5\% (b/v) gula ataupun urea saja menunjukkan penurunan yang nyata $(\mathrm{P}<0,05)$ terhadap degradasi NDF. Rendahnya degradasi NDF dengan menggunakan inokulum dari cairan feses kemungkinan disebabkan oleh jumlah mikroba yang relatif lebih sedikit dibandingkan dengan penggunaan inokulum cairan rumen. Dhanoa et al (2004) melaporkan bahwa rendahnya level microba yang bertahan dalam cairan feses menunjukkan pengurangan potensi mendegradasi sampel pakan. Penambahan gula dan urea yang merupakan sumber energi dan nitrogen diduga dapat meningkatkan populasi mikroba seperti pada perlakuan C, sehingga dapat meningkatkan degradasi NDF

Tabel 1. Degradasi in vitro NDF, ADF dan Protein kasar dari rumput raja

\begin{tabular}{cllc}
\hline Perlakuan & NDF & ADF & Protein kasar \\
\hline A & $56.96 \mathrm{~b}$ & $46.09 \mathrm{a}$ & $32.84 \mathrm{a}$ \\
B & $51.75 \mathrm{~d}$ & $39.96 \mathrm{~b}$ & $27.09 \mathrm{~b}$ \\
C & $45.77 \mathrm{e}$ & $30.10 \mathrm{e}$ & $20.61 \mathrm{~d}$ \\
D & $57.83 \mathrm{a}$ & $38.72 \mathrm{c}$ & $20.89 \mathrm{~d}$ \\
E & $53.07 \mathrm{c}$ & $34.68 \mathrm{~d}$ & $25.02 \mathrm{c}$ \\
\hline
\end{tabular}

Keterangan:

A: cairan rumen

B: Cairan Feses

C: Cairan feses dan $2,5 \%(\mathrm{~b} / \mathrm{v})$ gula

D: Cairan feses, $2,5 \%(\mathrm{~b} / \mathrm{v})$ gula dan $2,5 \%(\mathrm{~b} / \mathrm{v})$ urea

E: Cairan feses dan $2,5 \%(b / v)$ urea

$\mathrm{b} / \mathrm{v}$ : berat/volume

Degradasi ADF dari RR pada penelitian ini juga menunjukkan perbedaan nyata $(\mathrm{P}<0,05)$ di antara masing-masing perlakuan (Tabel 1). Perlakuan kontrol menggunakan cairan rumen saja menunjukkan menunjukkan masih rendahnya degradasi ADF. Kemungkinan relatif kurang berkembangnya mikroba penghasil enzim selulosa dalam cairan feses. Ini diduga sesuai dengan alur-alur ekstraksi detergen dalam analisin serat (Van Soest,1963).

Degradasi protein kasar dari RR pada penelitian ini juga menujukkan perbedaan nyata $(\mathrm{P}<0,05)$ di antara masing-masing perlakuan (Tabel 1). Perlakuan masih memberikan pengaruh nyata $(\mathrm{P}<0,05)$ di antara mesing-masing perlakuan. Degradasi protein kasar 
dengan menggunakan cairan feses masih jauh lebih rendah bila dibandingkan dengan penggunaan cairan rumen. Diduga populasi mikroba pendegradasi protein yang masih rendah populasinya dalam cairan feses, sehingga berkurangnya potensi untuk mendegrasi protein (Dhanoa et al, 2004)

\section{KESIMPULAN DAN SARAN}

\section{Kesimpulan}

Penggunaan cairan feses ataupun penambahan sumber energi maupun protein dalam penelitian in vitro masih belum menunjukkan hasil yang optimal jika dibandingkan dengan penggunaan cairan rumen, sehingga terlihat masih rendahnya degradasi ADF dan protein kasar kecuali ADF.

\section{Saran}

Perlu penelitian lebih lanjut mengenai pengoptimalan jumlah pupolasi mikroba di dalam cairan feses agar dapat menyamai jumlah mikroba yang ada dalam cairan rumen

\section{UCAPAN TERIMAKASIH.}

Ucapan terimakasih yang tak terhingga kepada Unversitas Jambi melalui dana PNBP Universitas yang telah mendanai penelitian ini.

\section{DAFTAR PUSTAKA}

Afdal, M dan M Toha. 2007. Pemanfaatan inokulum feses sapi dalam uji kecernaan in vitro rumput kumpeh (Hymenachne amplexicaulis). (The utilization of faecal inoculum of cow to investigate the in vitro digestibility of kumpeh grass (Hymenachne amplexicaulis). J Indon. Trop. Anim. Agric. 32 (3) Sep 2007 : 201-206
Balfe, B. 1985. The development of a two stage technique for the in vitro digestion of hay using ovine faeces (instead of rumen liquor) as a source of microorganism BSc (horn) Disertation University of Wales. Bangor UK

Dhanoa, M.., J. France., L. A. Crompton., R. M. Mauricio., E. Kebreab., J. A. N. Mills., R. Sanderson., J. Dijkstra dan S. Lopez. 2004. Technical note: A proposed method to determine the extent ofdegradation of a feed in the rumen from the degradation profile obtained with the in vitro gas production technique using feces as the inoculum. Journal of Animal Science 82:733-746

Sudirman, R. Utoma., Z. Bachrudin., B. P. Widyobroto, dan Suhubdy. 2006. An evaluation of in vitro method using buffalo faeces as a sources of inoculum for the measurement of tropical feed digestibility. Proceeding of the 4 th International Seminar on Tropical Aniimal production. November 8-9 2006 Yokyakarta

Tilley, J. M. A dan R. A. Terry. 1963. A two stage technique for the in vitro digestion of forage crops. Journal of the British Grassland Society 18:104-111

Van Soest, P. J. 1963. Use of detergents in the analysis of fibrous feeds. II A rapid method for the determination of fiberand lignin. J. Assoc. Off. Anal. Chem. 46:829-835

Zicarelli, F., S. Calabrò., M. I. Cutrignelli., F. Infascelli., R. Tudisco., F. Bovera., dan V. Piccolo. 2011. In vitro fermentation characteristics of diets with different forage/concentrate ratios: comparison of rumen and faecal inocula. Journal of the science of food and agriculture vol 91 issue 7 May 2011 :1213-1221 https://doi.org/10.1002/ jsfa. 4302 